\title{
Taxation and Budget Reform Commission (TBRC) Statutory Recommendation: Requiring Certain Constitutional Officers, Boards, and Other Taxing Authorities to Submit Line Item, Zero-Based Budgets to County Commissions 1
}

Rodney L. Clouser ${ }^{2}$

A series of 16 fact sheets has been written on statutory and constitutional proposals adopted by the Taxation and Budget Reform Commission (TBRC). The publications in this series can be accessed at http://edis.ifas.ufl.edu. Fact sheets FE733 through FE741 address statutory changes and fact sheets FE742 through FE748 address constitutional amendments. These fact sheets should not be considered as an all-inclusive assessment of the statutory or constitutional changes recommended by the Taxation and Budget Reform Commission. Some details of proposed changes may not have been discussed due to space limitations. These fact sheets are not intended as a replacement for personal knowledge about actual or proposed changes but are a guide to inform the public on the issues.

\section{Introduction}

The Taxation and Budget Reform Commission (TBRC) has made a statutory recommendation to the
Florida Legislature concerning submission of line item, zero-based budgets for certain constitutional officers, boards, and other taxing authorities to the county commission. The TBRC recommendation requires submission of the line item, zero-based budgets to the county commission prior to budget hearings by the county commission.

\section{TBRC Recommendations}

The statutory recommendation drafted by the TBRC is generic and somewhat vague. The entire recommendation consists of one paragraph. This recommendation requires certain constitutional officers, boards, and other taxing authorities to submit line item, zero-based budgets to the county commission prior to the beginning of county commission budget hearings. This requirement only applies to these groups if they receive revenue from ad valorem taxes or fees. The recommendation by the TBRC specifically excludes the county commission,

1. This is EDIS document FE741, a publication of the Food and Resource Economics Department, Florida Cooperative Extension Service, Institute of Food and Agricultural Sciences, University of Florida, Gainesville, FL. Published July 2008. Please visit the EDIS website at http://edis.ifas.ufl.edu.

2. Rodney L. Clouser, professor and extension public policy specialist of the Food and Resource Economics Department, Florida Cooperative Extension Service, Institute of Food and Agricultural Sciences, University of Florida, Gainesville, FL.

The Institute of Food and Agricultural Sciences (IFAS) is an Equal Opportunity Institution authorized to provide research, educational information and other services only to individuals and institutions that function with non-discrimination with respect to race, creed, color, religion, age, disability, sex, sexual orientation, marital status, national origin, political opinions or affiliations. U.S. Department of Agriculture, Cooperative Extension Service, University of Florida, IFAS, Florida A. \& M. University Cooperative Extension Program, and Boards of County Commissioners Cooperating. Larry Arrington, Dean 
county taxes, and county property appraisers from the line item, zero-based requirements.

What is zero-based budgeting? Defined in simplest form, zero-based budgeting requires units of government, or in the case of the TBRC recommendation, constitutional officers, boards, and other taxing authorities, to justify total budgets every fiscal year, rather than making budget allocations or appropriations based on the previous year's budget. The concept of zero-based budgeting is not new, and is already being used by several Florida county governments.

What does the line-item concept imply? The line-item requirement implies some level of detail in the budgets submitted to the county commission, rather than a gross number for a department or unit of local government. The level of detail is not specified in the statutory recommendation by the TBRC. However, it may include items such as operating and capital requests, personnel and salary requests, etc. Again, some counties in Florida already use and request line-item information.

\section{Impact of Proposed Statutory Change}

The impact of the TBRC recommendation appears to be minimal. The recommendation has no impact on taxes or fees. The primary impact will most likely be on personnel resources of the constitutional officers, boards, and other taxing authorities in preparation of their budgets. For those "officers" not familiar with zero-based budgeting, some effort will be required to become informed about the process.

Why even worry about line item, zero-based budgeting? Some individuals and groups, especially fiscal watchdog groups, might suggest that the approach helps temper growth in budgets and expenditures while helping curb unnecessary spending. Others may believe this approach has no impact on growth in budgets.

It is possible, especially in counties where limited information is required from constitutional officers, boards, and other taxing authorities, that line item, zero-based budgeting will increase transparency in budget requests and provide useful information on expenditure requests by the various units of government within counties.

TBRC staff analysis specifically notes that 95 special districts have ad valorem taxes as a revenue source. These special districts have members of their boards selected in different manners, and some districts cover multi-county areas. Therefore it could be difficult for these special districts to comply with the suggested statutory recommendations.

Although the statutory recommendation does not specify the exact nature and what items to include in the line-item requirement, some people may feel it oversteps the appropriate boundaries of state government in terms of "mandating" how local governments should operate.

Finally, it is interesting to note that that two of the five county-elected constitutional officers are exempt from the requirements of the TBRC recommendation: the tax collector and the property appraiser. This could lead to some friction with other county constitutional officers (clerk of courts, sheriff, and supervisor of elections) as to why they would be subject to compliance with the requirements when other elected officials are not.

\section{Summary}

Although the statutory recommendations have been made by the TBRC, and in some instances with specific dates to become effective, the Florida Legislature and the Governor are not bound to the effective dates or the recommendations. Before these recommendations become law, they require approval of both the Florida Senate and House, and approval by the Governor. Citizens interested in the specific recommendations will need to follow the progress of the issue through the legislative process.

Additionally, there is no time limit for action by the legislature on the TBRC recommendations and they can be introduced in any future legislative session after initial submission by the TBRC.

\section{References}

Florida Taxation and Budget Reform Commission. 2008. SR49E1: an act relating to local 
governments. TBRC, Tallahassee, FL (April).

http://www.floridatbrc.org/pdf/SR49E1_final.pdf

Florida Taxation and Budget Reform

Commission. 2008. CS/SR 49 Staff Analysis and

Economic Impact Statement. TBRC, Tallahassee, FL

(April).

http://www.floridatbrc.org/pdf/

SR49ApprovedFinal.pdf

Florida Taxation and Budget Reform

Commission. 2008. Transmittal letter. TBRC,

Tallahassee, FL (April).

http://www.floridatbrc.org/pdf/

3_18_08TransmittalLtrSR49Engrossed.pdf 